\title{
Isolation and characterization of microsatellite loci for the endangered Midwife Betic toad Alytes dickhilleni (Discoglossidae)
}

\author{
Eva M. Albert • Juan M. Arroyo · José A. Godoy
}

Received: 27 September 2010/ Accepted: 8 October 2010

(C) Springer Science+Business Media B.V. 2010

\begin{abstract}
We have developed eleven polymorphic microsatellite loci for the amphibian Alytes dickhilleni using an enriched-library approach. We detected 98 alleles in 50 individuals genotyped (mean number of alleles per locus was 8.91) in two different populations in South East Spain. Expected heterozygosities ranged from 0.324 to 0.891 in one population (Arroyo Guadahornillos) and 0.424-0.909 in the other population (Cueva Paria). The levels of polymorphism of the developed markers render them readily applicable for population genetic studies of diversity, structure, and migration.
\end{abstract}

Keywords Alytes dickhilleni - Amphibian decline · Iberian Peninsula $\cdot$ SSR

Amphibians are among the groups of vertebrates pronest to extinction process upon habitat perturbation (Stuart et al. 2004). Among their main threats, the fragmentation of the habitat and the desiccation and contamination of the ponds were they breed are often highlighted. In the last decade, the emergence of a disease known as Chytridiomycosis, produced by the lethal fungus Batrachochytrium dendrobatidis, has killed thousands of individuals around the world, bringing amphibians in the focus of conservation programs. The Betic Midwife toad, Alytes dickhilleni (Arntzen and García-París 1995), is one of the Iberian amphibian species that have been seriously affected by the transformation of the habitat (García-París 2002; GarcíaParís et al. 2004). With a distribution restricted to the

E. M. Albert $(\bowtie)$. J. M. Arroyo · J. A. Godoy

Department of Integrative Ecology, Estación Biológica de Doñana (CSIC), c/Américo Vespucio, s/n, 41092 Sevilla, Spain

e-mail: eva.albert@ebd.csic.es southeastern part of the Iberian Peninsula, the Betic Midwife toad lives in rocky mountain areas inhabited by farmers, where the competition for water with humans is really high. Adults usually breed in small streams or in cattle through used to assure fresh water provision to domestic animals (García-París 2002). In the last few years A. dickhilleni populations have rapidly declined in all their range, mainly because of the elimination, modification, or cleaning of cattle troughs by farmers (García-París et al. 2004). In order to investigate global and local patterns of genetic variation and estimate effective population size and migration rates between ponds, we have developed 11 highly variable microsatellite loci for the Betic Midwife toad.

We developed microsatellite libraries following Jones et al. (2002). We extracted approximately $100 \mu \mathrm{g}$ of genomic DNA of one individual using the QIAGEN DNeasy Tissue Extraction kit. The DNA was partially restricted with seven blunt-end restriction enzymes (RsaI, HaeIII, BsrB1, PvuII, StuI, ScaI and EcoRV). Fragments (300-750 bp) were ligated with 20-bp oligonucleotides containing a HindIII site at the $5^{\prime}$ end, and subjected to magnetic bead capture.

Four libraries were prepared in parallel using Biotin$\mathrm{CA}_{15}$, Biotin-GA 15 , Biotin-ATG 12 and Biotin-AAC 12 as capture molecules (CPG Inc.). Captured molecules were amplified and restricted with HindIII to remove the adapters, and the resulting fragments were ligated into the HindIII site of pUC19 plasmid and introduced into Escherichia coli DH5 $\alpha$ by electroporation. One hundred recombinant clones were selected at random for sequencing and 73 of them contained a microsatellite sequence. Polymerase chain reaction (PCR) primer pairs were designed for 44 clones using DESIGNER per 1.03 (Research Genetics Inc.). 


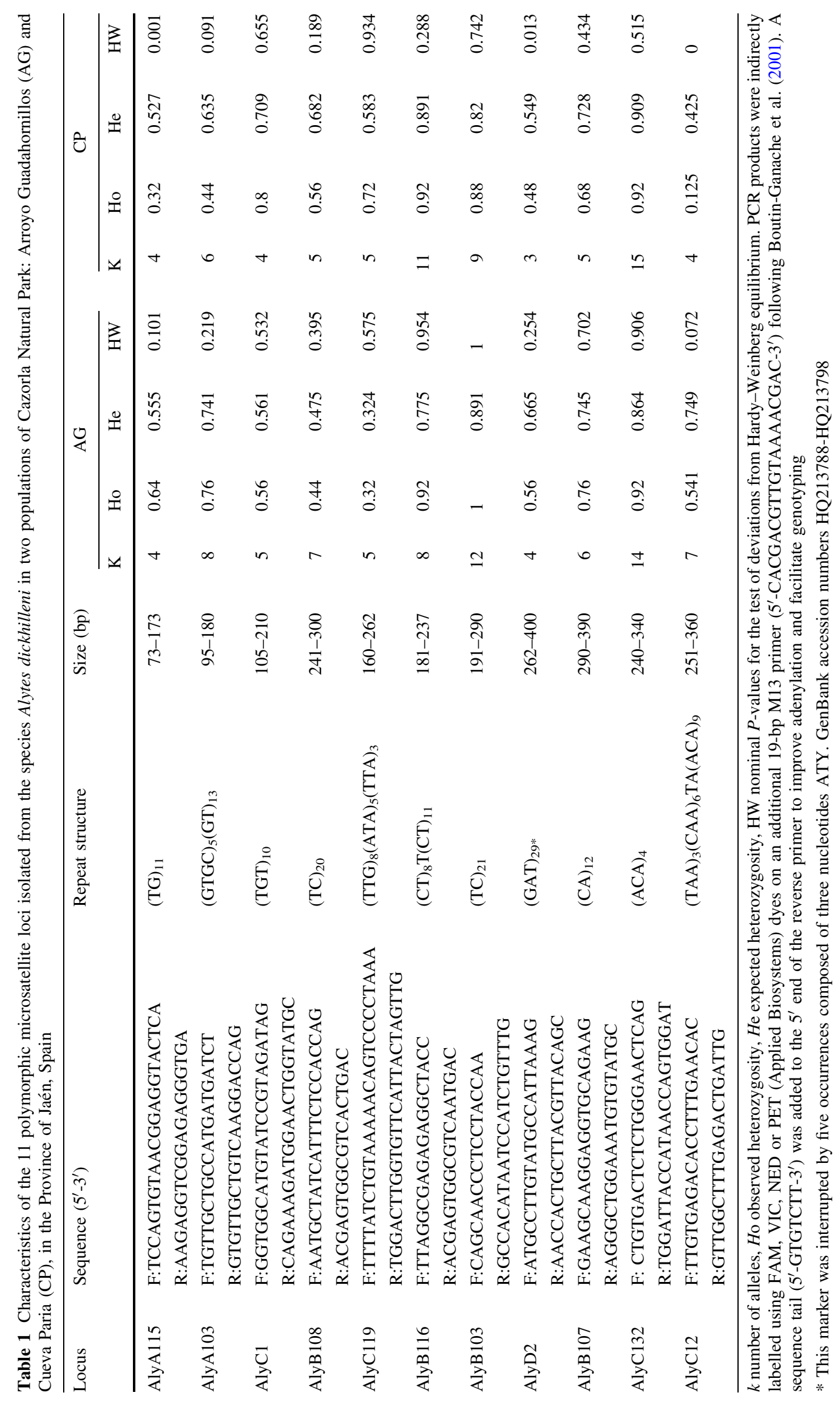


For primer testing, we isolated DNA from toe clips from adults and tail tips from tadpoles in 25 individuals collected in two populations: Cueva Paria (CP) and Arroyo Guadahornillos (AG), both in the Natural Park of Cazorla, Segura y las Villas, Jaén Province, Spain, using a standard phenol/chloroform extraction DNA protocol (Sambrook et al. 1989). Polymerase chain reactions were performed in final volume of $20 \mu \mathrm{L}$ containing $1 \times$ buffer [67 mM Tris- $\mathrm{HCl} \mathrm{pH} 8.8,16 \mathrm{mM}\left(\mathrm{NH}_{4}\right){ }_{2} \mathrm{SO}_{4}, 0.01 \%$ Tween-20], $2.5 \mathrm{mM} \mathrm{MgCl}_{2}, 0.01 \%$ BSA, $0.25 \mathrm{mM}$ dNTP, $0.40 \mu \mathrm{M}$ dye-labelled M13 primer, $0.40 \mu \mathrm{M}$ tailed-reverse primer, $0.04 \mu \mathrm{M}$ M13 tailed-forward primer, 0.5 U Taq DNA polymerase (Bioline) and $50 \mathrm{ng}$ of genomic DNA. Samples were amplified with a 'touchdown' PCR in a BIO-RAD DNA Engine Peltier Thermal Cycler, with an initial denaturation step of $2 \mathrm{~min}$ at $94^{\circ} \mathrm{C} ; 17$ cycles at $92^{\circ} \mathrm{C}$ for $30 \mathrm{~s}$, annealing at $60-44^{\circ} \mathrm{C}$ for $30 \mathrm{~s}$ $\left(1^{\circ} \mathrm{C}\right.$ decrease in each cycle) and extension at $72^{\circ} \mathrm{C}$ for 30 $\mathrm{s} ; 25$ cycles at $92^{\circ} \mathrm{C}$ for $30 \mathrm{~s}, 44^{\circ} \mathrm{C}$ for $30 \mathrm{~s}$ and $72^{\circ} \mathrm{C}$ for $30 \mathrm{~s}$ with a final extension for $5 \mathrm{~min}$ at $72^{\circ} \mathrm{C}$. Amplified fragments were analyzed on an ABI 3130xl Genetic Analyser and scored using GeneMapper 4.0 (Applied Biosystems) and LIZ 500 size standard.

We tested a total of 44 primer pairs from which we finally retained 11 polymorphic markers after inspecting their observed and expected heterozygosities (Cervus 3.0; Kalinowski et al. 2007) and testing for deviations from Hardy-Weinberg equilibrium, gametic disequilibrium (GenePop 4.0; Rousset 2007), and the presence of null alleles (Micro-Checker 2.2.3; Oosterhout et al. 2004). We used Bonferroni corrected $P$-values to assess the significance of multiple tests.

From the 11 loci selected, we detected a total of 80 alleles in AG and 71 alleles in CP, with individual locus values ranging from 4-14 to 3-15 alleles, respectively. The expected heterozygosity ranged from 0.324 to 0.891 in $\mathrm{AG}$ and from 0.424 to 0.909 in CP (Table 1). Two loci showed a significant deviation of the Hardy-Weinberg equilibrium in one population after Bonferroni corrrection (AlyC12 and AlyA115 in population CP). The presence of null alleles was suggested by Micro-Checker as a likely cause for the observed heterozygote deficit for these two loci and AlyA103 in CP and for AlyC12 in AG.
The microsatellite markers described in this study provide a valuable tool for the analysis of the demographic and genetic consequences of habitat fragmentation and human pressure on populations of the Betic Midwife toad.

Acknowledgments The study was supported by Junta de Andalucía, Consejería de Economía, Innovación y Ciencia (P07-RNM02928). We acknowledge to the staff of Cazorla Natural Park for technical support and to the people who kindly helped in the field sampling or provided samples: Jaime Bosch, Marc Antoine Marchand, Jordi Bascompte, Emilio Miras and Maribel Benítez. We thank Jordi Bascompte for helpful comments of this work.

\section{References}

Arntzen JW, García-París M (1995) Morphological and allozyme studies of midwife toads (genus Alytes), including the description of two new taxa from Spain. Bijdragen tot de Dierkunde 65:5-34

Boutin-Ganache I, Raposo M, Raymond M, Deschepper CF (2001) M13-tailed primers improve the readability and usability of microsatellite analyses performed with two different allelesizing methods. BioTechniques 31:24-27

García-París M (2002) Triturus pygmaeus (Wolterstorff, 1905). Tritón pigmeo. En: Pleguezuelos JM, Márquez R, Lizana M (eds) Atlas y libro rojo de los anfibios y reptiles de España. Dirección General de Conservación de la Naturaleza-Asociación Herpetólogica Española ( $2^{\mathrm{a}}$ impresión). Madrid, pp 70-72

García-París M, Montori A, Herrero P (2004) Fauna Ibérica, vol 24: Amphibia. Lissamphibia. Museo Nacional de Ciencias Naturales. Consejo Superior de Investigaciones Científicas, Madrid

Jones KC, Levine KF, Banks JD (2002) Characterization of 11 polymorphic tetranucleotide microsatellites for forensic applications in California elk (Cervus elaphus canadensis). Mol Ecol Notes 2:425-427

Kalinowski ST, Taper ML, Marshall TC (2007) Revising how the computer program CERVUS accommodates genotyping error increases success in paternity assignment. Mol Ecol 16:10061099

Oosterhout CV, Hutchinson WF, Wills DPM, Shipley P (2004) Micro-Checker: software for identifying and correcting genotyping errors in microsatellite data. Mol Ecol Notes 4:535-538

Rousset F (2007) Genepop'007: a complete re-implementation of the Genepop. Mol Ecol Resour 8:103-106

Sambrook J, Fritsch EF, Maniatis T (1989) Molecular cloning: a laboratory manual. 2nd edn. Cold Spring Harbor Laboratory, Cold Spring Harbor Laboratory Press, NY, $1659 \mathrm{p}$

Stuart SN, Chanson JS, Cox NA, Young BE, Rodrigues ASL, Fischman DL, Waller RW (2004) Status and trends of amphibian declines and extinctions worldwide. Science 306:1783-1786 